\title{
CITY LOGISTICS - STATUS AND TRENDS
}

\author{
Snežana Tadić ${ }^{1}$, Slobodan Zečević ${ }^{2}$, Mladen Krstić ${ }^{3}$ \\ ${ }^{1,2,3}$ University of Belgrade, Faculty of Transport and Traffic Engineering, Vojvode Stepe 305, 11000 \\ Belgrade, Serbia
}

Received 1 March 2015; accepted 8 July 2015

\begin{abstract}
City logistics aims to increase the efficiency and mitigate the negative effects of logistics processes and activities, and at the same time support the sustainable development of the urban areas. Major European and national research projects, undertaken from the end of the last century onwards, indicate that the state of the urban area logistics is quite critical. The situation requires a comprehensive analysis and active participation of the authorities and companies in order to solve the growing problems and define the sustainable solutions which would encourage the economic development and improve the living conditions in the city. In order to make logistics activities less routine, and thereby more efficient, many initiatives have been launched, especially in the terms of environmental impact and service quality. However, the changes are slow and environmental trends are setting new challenges. The main problem is the lack of planning activities and comprehensive and long term policy of city logistics. Decisions of city planners are often inadequate, without the analysis of existing situation and interaction of city logistics and complex socio-economic system of the city and its surrounding, without research and studies of different measures and impacts on the overall city logistics system. This article presented the current situation and trends in the implementation of logistics chains within the urban areas in order to highlight the complexity of solving the problems of a complex city logistics system.
\end{abstract}

Keywords: city logistics, distribution, sustainable development, integrated planning, logistics services, logistics sub-urbanization, logistics outsourcing, loading factor, environmental impact.

\section{Introduction}

With the growth of the urban population (UN - United Nations, 2012), the volume of goods and traffic flows are also growing. Expansion and economic empowerment of the city are the main driving forces, and simultaneously the "victims" of the development of city logistics and freight transportation (Loffler, 1999). Cities depend on the logistics systems efficiency, therefore their further development and economic progress are closely linked to the further expansion of the logistics activities, primarily transportation. Therefore, it is impossible to significantly reduce road freight transport, not affecting thereby the needs of the city and its inhabitants. On the other hand, with the growth of the vehicle-kilometers, the environmental impacts are also growing and congestion in urban areas threatens to become an even bigger problem. However, despite the complex interdependencies and major problems, city administration, politicians and planners pay very little attention to logistics and freight transport.

\footnotetext{
${ }^{1}$ Corresponding author: s.tadic@sf.bg.ac.rs
} 
Current situation requires detailed analysis, immediate intervention and long-term solutions.

In order to comprehend the dimensions of city logistics, it is desirable to know the characteristics of logistics, transport and goods flows, as well as the systems that enable their implementation. The volume of flows is directly related to the size of the city. However, in addition to consumer goods, it is necessary to examine the flows of intermediate goods, raw materials, construction materials and other various cargos. On the other hand, the flows volume largely depends on the geographical and spatial characteristics, spatial organization of urban functions, logistics infrastructure and the role of the observed area in the goods flow realization on a higher level. Therefore, the flow volumes in the cities which are important logistical nodes (gateway or hub systems) are significantly higher as a result of the transit flows i.e. the role of logistics systems in the realization of global, regional and national flows.

Although the dimensions and characteristics of the goods and transport flows vary from city to city, major research projects undertaken from the end of the last century onwards, mostly in developed countries, indicate that the requirements for delivering/ collecting the goods nevertheless converge. It can be said that the city generates about (Dablanc, 2009):

- $\quad 0,1$ delivery/collection per capita per day;

- 1 delivery/collection per job per week;

- 300 to 400 truck drives per 1000 inhabitants per day; and

- 30 to 50 tons of goods per capita per year.
These flows include all goods movements generated by the needs of economic entities, all deliveries and collection of the basic goods, materials, auxiliary materials and consumables, mail and waste materials, as well as home deliveries resulting from the distance selling (e-commerce). The analyzes doesn't generally include two important categories of flows: flows of private carriage of goods by the individuals, citizens, for their own purposes (shopping trips) and transit flows, i.e. the vehicles that circulate through the city, but not with the aim of meeting the demands of an enterprise or a household in the urban environment. In large European cities, shopping trips (made by the cars of end consumers) make up between 45 and 55\% of the urban goods movements (GonzalezFeliu et al., 2012) and may participate with $15-20 \%$ of the total vehicle-kilometers (Dablanc, 2009). Likewise, transit flows can significantly burden the city's transport network and disrupt the living conditions. For these reasons, these categories of flows should be included in the definition of urban planning documents with the aim of the efficient functioning of the city as a whole.

The logistics industry is influenced by a number of global trends (Tadić et al., 2013a), and the organization and implementation of logistics activities in the city depends on a number of factors that describe the complex social and economic system of the city and its surroundings (Tadić, 2014). These factors are variable categories, and their analysis can identify the problems and directions for future development of the city logistics.

For the purpose of admissibility, successful implementation and sustainability of solution, appropriate methods should encourage the participation of all stakeholders in its creation and the effects, 
i.e. the consequences for the entire system of the city logistics should be considered. However, changes in the problem solving approaches and integrated planning require a certain level of understanding of the nature of logistics activities, which is usually not the case (Tadić and Zečević, 2015).

\section{The Importance of City Logistics}

Although it is the least monitored and planned, road freight system has a strong urban component. Ogden (1992) states that in the US (United States) about $30 \%$ of the total kilometers traveled by the road freight vehicles (with the payload of over 3.5 tones) are carried out within the large urban areas. According to the estimates of the European Conference of Ministers of Transport (ECMT) urban freight transport makes 34\% of the total freight transport, occupies $20 \%$ of the entire transport network (network occupied $\mathrm{x}$ hour) and produces $60 \%$ of the total emissions (OECD - Organisation for Economic Co-operation and Development, 2003). In addition, commercial vehicles with the gross weight exceeding the 3,5 tones, which are being used for the distribution of goods in the urban areas, make up $10 \%$ of the total number of vehicles on the street network of the European cities, and their participation in the urban traffic flows (vehicle-kilometers) is within $10-20 \%$. Given that smaller delivery vehicles (vans and pick-up vehicles) and passenger cars are increasingly used for the distribution of goods, this share of freight transport is significantly higher. The realization of logistics flows in the urban areas engages $2-5 \%$ of the employed labor force, while the logistics systems occupy 3-5\% of the urban land (EC - European Commision, 2007a). The city is not only the ultimate destination of the cargo flows, but also the place from which the goods are shipped. From the perspective of the origin and destination of cargo flows, $20-25 \%$ of the freight vehiclekilometers in the city are the flows shipped from the city, $40-50 \%$ are the flows entering the city, and the rest are the inner city flows (Dablanc, 2009). Researches show that the difference between the volumes of incoming and outgoing flows is increasing as a result of the production decline in the urban areas (Allen and Browne, 2010).

Analysis of the logistics costs also shows the importance of city logistics. Logistics costs include the cost of packaging, manipulation, transportation, warehousing, inventory and administrative costs from ordering raw materials to delivery of the final product to the end user. Since the 80 s of the last century, the share of these costs decreased from $12.1 \%$ to $6.1 \%$, while the share of transport costs decreased from $5.9 \%$ to $2.6 \%$ (ELA - European Logistics Association, 2004). However, in the middle of the last decade, first there was the stagnation and then the growth of these costs. According to the Council of Supply Chain Management Professionals (CSCMP), logistics costs are accounted for $9.9 \%$ of the US GDP (Gross Domestic Product) in 2007, and fell to $7.9 \%$ of the GDP in 2009, as a result of the recession. Since then, they grow (amounted to $8.5 \%$ of the GDP in 2011), but are still lower than before the recession (CSCMP, 2012). The Canadian studies showed that transport costs in the urban areas are 2.6 times higher than the costs in the suburbs (Ogden, 1992). UPS (United Parcel Service), one of the largest operators of express delivery in the world, estimated that the delivery costs to New York are about 30\% higher than the average costs in the rest of the country (IAURIF - Institut d'aménagement et d'urbanisme d'Ile-de-France, 1999). 
Researches from the beginning of the $21^{\text {st }}$ century in Europe showed that the share of the costs of collection and delivery of goods (mainly in the urban areas) are about $40 \%$ of the total costs of the door to door service in the combined transport flows. According to the present trends it is estimated that these costs will grow (PORTAL, 2003). Transport operators in France stated that the costs of urban and intercity parts of the transportation are equal (Dablanc, 2009). According to the CSCMP estimates, about $28 \%$ of the total transportation costs are incurred by the realization of the last mile (Goodman, 2005). Share of the final distribution costs in the total transportation costs of the logistics chain depends on the number of users, characteristics of the shipment, reliability as the consequence of the traffic congestion, etc. (Rodrigue et al., 2009). High costs indicate the inefficiency of urban freight transport. Local authorities in the European cities have undertaken various regulatory and incentive measures, with the aim of increasing consolidation, cooperation and coordination, and raising the efficiency of the city logistics, primarily urban freight transport. Impact analysis of the applied initiatives highlights the complexity of the problem (Danielis et al., 2010) because the results vary, particularly from the perspective of the environment. The impact analysis of the delivery time intervals in the Netherlands determined the average delivery costs for the retails in all parts of the city and shopping areas, but also for the entire retail sector including the food retail. Goods delivery costs for the shopping areas were higher due to the access restrictions (time intervals and limitations concerning delivery vehicles). On the other hand, the food retail sector had lower costs of transport and logistics, compared with overall retail sector, due to the presence of large retail chains with efficient organization of logistics activities (TNO - Toegepast Natuurwetenschappelijk Onderzoek, 2003).

The aforementioned facts indicate that the city logistics is one of the key factors of the urban sustainability. Distribution of goods provides the vital functions of the city. However, efficient realization of the supply flows is a necessary but not sufficient condition of life within the city. Normal functioning of the city requires efficient realization of the reverse flows, i.e. the extraction of waste, secondary raw materials and recycling materials. The importance of reverse flows is proven by the fact that between 1990 and 1995 waste production in Europe increased by $10 \%$, and according to OECD estimates it will increase by $45 \%$ by 2020 , compared to the level from 1995 (EC, 2004). In 2006, the EU-27 produced 3000 million tons of waste, or about six tons per capita. There are significant differences in the generation of waste between countries, mainly due to various industrial and socio-economic structures. Municipal waste varies by a factor of 2.6 between countries, and in 2008 was on average $524 \mathrm{~kg}$ per capita in the EU-27 (EEA - European Environment Agency, 2010a). The packaging waste originating from the households and commercial sector accounts for about $3 \%$ of the total waste and varies across countries, ranging from $40 \mathrm{~kg}$ per capita in Bulgaria, to $232 \mathrm{~kg}$ in Ireland (EEA, 2010b). Economic development has caused the growth of production and consumption and shortening of the product life cycle, increasing thereby the amount of waste materials. Similarly, the presence of the inadequately packaged products, especially in terms of transport, in the distribution flows is increasing, further reducing the efficiency of the logistics activities in the city. Reverse 
flows of the expired goods, seasonal goods or perishable food products, in addition to the requirements for the collection of packaging and freight handling units, impose significant and highly complex requirements.

The fact that the quantity of the delivered goods and the number of the vehicles launched are reversely proportional, also points to the problems of the urban logistics. The reverse proportionality is the consequence of a large share of the small capacity vehicles in the realization of flows and lower utilization of the cargo space. Obviously, the possibility of aggregating demands in time and space is not utilized enough. Volkswagen's research from the 90 s of the last century showed that $85 \%$ of the weekly deliveries of goods were realized with $5 \%$, and the remaining $15 \%$ of the amount with $95 \%$, of the total number of launched vehicles (Esser and Petry, 1993). In Lausanne, $52 \%$ of the goods are delivered by $88 \%$ of the launched vans, while the remaining goods $(48 \%)$ are transported with $12 \%$ of launched freight vehicles (gross vehicle weight exceeding 3.5t) (PORTAL, 2003). For these reasons, the goal of city logistics is the harmonization of supply and demand, or the overall optimization of logistics flows in the city. In the past there were individual attempts of aggregation and consolidation of the cargo flows, but since it is mostly done on the initiative of the private sector (groups of logistics providers, freight forwarders), capabilities and effects were limited. However, today this is an approach that developed European cities are increasingly trying to impose, due to the aforementioned economic and environmental reasons.

\section{Basic Characteristics and Trends of the City Logistics}

Goods and transport flows in the city are the result of the logistical decisions, i.e. the processes necessary for the organization of an efficient delivery and collection of goods. Logistics decisions, based on the requirements of the production and distribution sector, depend on the behavior of economic actors, such as households and companies. On the other hand, the spatial organization of industrial, commercial and logistics systems, but also the present legal framework and regulations have a direct impact on the planning, organization and implementation of the logistics activities in the city. These interactions provide the complex characteristics of city logistics and logistics chains in the city (Fig. 1). One of the characteristics is that the implementation of goods flows generally do not depend on the internal structure of the city, although it has a significant impact on the total number of freight vehicle-kilometers, and thus to other economic and environmental parameters. Each activity (trade, service, industrial, administrative, etc.) can be associated with a specific profile of generating the flow of goods, which is identical for all urban areas. From the logistics perspective, freight flow generator (trade, catering facility, pharmacy, bakery, bank, warehouse, etc.) works in the same or a similar manner regardless of whether it is in the center of a big metropolis or in the suburbs of a medium large city. This and other characteristics of the city logistics and logistics chains are described in detail below. 


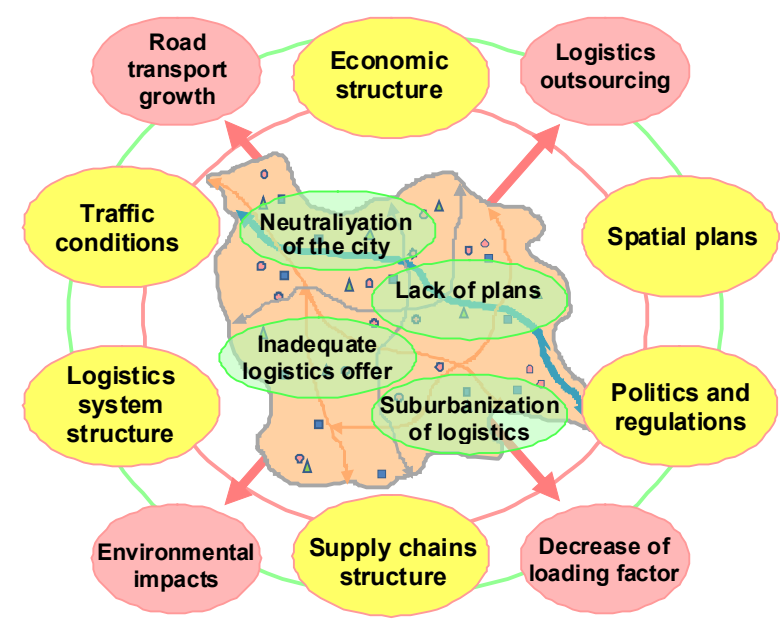

Fig. 1.

Characteristics and Trends of City Logistics

\section{1. „Neutralization" of the City from the City Logistics Perspective}

From the city logistics perspective, some kind of "neutralization" of the city's territory is noticeable. Deliveries are carried out in a similar manner in all cities, regardless of their differences (Dablanc, 2007). On the other hand, by analyzing the developed urban freight transport models, from the beginning of this century, it was found that the size and shape of the city have a significant impact on the performance of urban freight flows (Woudsma, 2001). Given that the transport is one of the logistics subsystems, definition and success of the city logistics conceptual solutions depend on the characteristics of the urban environment. Cities differ in demographic, geographic, economic, social, cultural, historical and other characteristics, therefore initiatives and concepts of city logistics do not have the same effect, and in some cities are not even applicable (Tadić et al., 2014c). The main problems are not always well defined, and the connection with the proposed measures and the characteristics of the city is not always present, although that is the goal. Due to the lack of knowledge, financial and human resources, and under the excuse of improving the economy and quality of life in the city, local governments often try to implement initiatives and concepts of city logistics solutions from other cities. However, the expected positive effects are absent, and in some cases problems and dissatisfaction of citizens and implementers of logistics activities increases. This indicates a noticeable lack of planning activities, i.e. the comprehensive and long-term policy of city logistics.

Generally, logistical decisions are often inadequate, without the necessary research, analysis and insight into the various objectives, criteria, measures and impacts. On the one hand, the logistics flows are under the influence of various 
parameters of the urban environment, such as infrastructure conditions, economic structure, spatial plans etc. On the other hand, the realization of logistics flows affects the different parameters of the urban environment, such as traffic congestion, accessibility, air pollution etc. Also, there is interdependence between the causes and effects of the implementation of logistics flows, for example, greater traffic congestion causes less efficient realization of the flows and vice versa (Tadić, 2014). Logistics and urban planning are complementary systems with strong interactions. The availability of logistics services, among other things, is determined by the location of the enterprise, and the decision on the location is made by the local administration in accordance with the spatial plan (Geurs and van Wee, 2004). In addition, the promotion and development of transport and logistics infrastructure and transport capacity may cause changes in logistics processes and activities and thus stimulate transport demand (Hesse and Rodrigue, 2004) and other requirements for the basic, auxiliary and supplementary logistics services. The location decision on the logistics center or warehouse, mainly takes into account only the property and geological characteristics of the land, even though the solution of this problem requires consideration of a large number of criteria, such as transport accessibility, availability, distance from major economic centers, availability of land for future expansion, etc. (Tadić et al., 2013b). However, on the city territory, the land is no longer an issue. It simply does not exist for the development of logistics activities. Since the city is a complex system, costly and full of limitations, in most cases it represents only a space for circulation, loading or unloading of goods. Very little permanent logistics systems and logistics service providers are located on the city's territory and operators use them only when it is necessary.

Beside the fact that it is not dependent on local conditions, city logistics is also characterized by some particularly negative characteristics of the logistics industry. This rather refers to the activity of urban freight transport, although the situation is similar in terms of storage, inventory and packaging. For example, there is a tendency for non-compliance with social and labor legislation (longer working hours), and the vehicles engaged in the distribution of goods in the city are usually older and thus less environmentally friendly than vehicles in the long haul transport. The reason for these negative characteristics is the high competition in the road transport industry, especially for small and mediumsized enterprises operating in the city. In order to ensure market share and reduce costs, many operators extend the lifetime of the vehicles or the number of working hours in the distribution of goods. On the other hand, small trade, distribution and logistics companies have conveniently settled existing logistics systems in the city, built a long time ago, often in the central urban areas, near railway freight station or airport, and developed their own warehouse and distribution activities. These systems are equipped with the outdated storage and manipulative technologies that reduce the efficiency of logistics processes and adversely affect the quality of services (Tadić et al., 2014a).

\subsection{The Lack of the City Logistics Plans}

Due to the negative impact of logistics activities on the environment, economy and quality of life in the city, local authorities are increasingly aware of the importance of 
organization and control over the execution of logistics chains, but mostly they do not know how to conduct them. Regardless of the measure adopted for organizing the logistics activities, goods will be delivered to the recipient at the time and place as a result of the logistics decision-making process. The reorganization is mainly performed through the reinforced regulation, i.e. the restriction of access for delivery vehicles. As the main actors are local authorities, the field of action is limited to the transport activity of a city. The main motive of the initiatives is a smaller number of vehicle-kilometers in the city, i.e. the reduction of the traffic congestion and improvement of the environmental conditions. However, the results of the application do not show the expected effects even in the terms of ecology. In addition, prohibitive and restrictive measures limit the realization of logistics activities, instead of making them more efficient and sustainable (Allen et al., 2000; Ballantyne et al., 2013; Dablanc, 2007; Holguin-Veras et al., 2013; Quak, 2008; Quak and de Koster, 2009; Tadić et al., 2014b). On the other hand, the relaxation of restrictions for freight vehicles can cause economic and environmental benefits (McKinnon, 2005), reducing the total delivery and collection time, and the number of vehicles in the urban areas (Anderson et al., 2005).

In fact, cities do not have a defined policy of city logistics. Laws governing logistics in the city do not exist, and regulations pertaining to urban freight transport are rare and mostly outdated. Restrictive measures concerning the load capacities of vehicles and times for accessing the particular city zone are applying for more than 30 years and did not change regardless of changes in the realization of the logistics chains (Dablanc, 2007). In fact, for the local authorities, the road freight transport is generally undesirable and should be prohibited or strictly regulated. In addition, the regulations are mainly of local nature and may be in conflict with those of neighboring municipalities. In one metropolitan area in France there are as many as 30 different regulations relating to capacity and size of vehicles, which obliges the logistics and transport companies to decide which rules will they respect, and which neglect (Dablanc, 2009). Rare are those cities in which the authorities consider logistics, especially transport activities, as the services that need help in order to be organized in a more efficient manner.

Generally, the analysis of city logistics initiatives (Tadić et al., 2014b; Tadić et al., 2014d) leads to several conclusions. First, the public sector, i.e. the local authorities do not know enough about the nature and problems of the realization of logistics activities in the city, while the logistics service providers did not sufficiently develop awareness of the need to achieve sustainability promoted by the local authorities. Second, the interaction between the private and public sectors is at a very low level, which causes the misunderstanding between the participants in the city logistics. Third, initiatives are destined to fail if the initiator is unable to realize their influences outside the self-defined area of operation (mainly the strictly limited space). Active participation in the initiatives demonstrates the willingness of the main actors to change their own behavior, even in the long run. This occurs in situations when the reasons for the implementation of initiatives are related to the reasons for the participation of the main actors.

Most of the city logistics initiatives require change of the logistics service providers' 
behavior, without prior analysis of the impact on their business performance. Rejection can be interpreted as a lack of the sufficient power and will of the providers to make their activities more sustainable, although they are responsible for their realization. However, initiatives cannot be successfully implemented unless they have a positive impact on logistics activities, i.e. logistics performances. Exceptions are the political initiatives that are forcing a change of behavior in accordance with the present legal measures. Such initiatives are considered unfair and induce resistance, which further requires the conditioning of the application in order to become operational in practice. In order to succeed, appropriate methods should be applied to encouraged participation in the initiatives, but this requires a certain level of understanding of the nature of logistics activities.

Existing policies, although not sufficiently systematic, are mostly dealing with the urban freight transport, and decisions are made without consulting all stakeholders and considering the consequences for the entire system of the city logistics. However, since the beginning of this century, the awareness of the importance of city logistics on the overall economic, environmental and social system is growing, and certain efforts are being made in the direction of changing approaches for solving the problems and integrated planning of this area. In some European cities, certain attempts to define a comprehensive strategy planning of the city logistics are recorded. The process of making master plans of urban logistics and freight transport, for the cities with over 100000 inhabitants, was launched in France. The plans are mostly finished, but few have been implemented. The authorities of the French metropolises did not have a sufficient budget, human resources or political power for the implementation of the defined measures and activities (Dablanc, 2007). In the UK (United Kingdom) cities, for years there have been consultations and negotiations of the local administration and logistics providers (FQP, Freight Quality Partnership) with the aim of understanding the interests and concerns of the participants of city logistics. These initiatives are supported at the national level by publishing guidelines and case studies (DfT - Department for Transport, 2003a, 2003b; Allen and Browne, 2010). In Barcelona, Spain, city authorities require that all new restaurants, bars and caterers have the storage space of at least $5 \mathrm{~m}^{2}$, so the supply of drinks and other goods would not have to be on a daily basis. Northern European cities (Amsterdam, Copenhagen, Stockholm, Gothenburg, etc.) apply access restrictions for delivery vehicles based on the environmental criteria, i.e. the negative impact on the environment. According to these regulations, only newer or fully loaded vehicles may enter the city center. These standards are intended to replace the earlier access restrictions related to the capacity and size of vehicles, which are now considered quite irrelevant. The above examples do not represent the models to follow. Although perhaps more innovative than the others, these cities did not yet resolve the problem, define the policy, nor adopt the concept of city logistics, i.e. they still do not have an efficient system of goods delivery. The system of control, through the regulations, restrictions and prohibitions, should support a certain concept of the city logistics, but should not be the solution itself.

The public sector, i.e. the administration of the city, should be the major initiator of solving the problems of city logistics. However, without the support of the 
private sector, the effects of the initiatives are limited. For this reason, the existing policies for solving the problems of goods distribution rely on the active participation of the private sector in defining the objectives and managing (Stathopoulos et al., 2012). Previously, the main objectives of the city logistics policies were to reduce the traffic congestion, while the current policies focus on a broader economic and environmental efficiency (Benjelloun et al., 2010). Besides that, more recent projects emphasized the implementation of initiatives related to the consolidation of flows. Application of the concept of consolidation and cooperation between the operators, i.e. carriers, gives the possibility to reduce the flows, which is in fact the main objective. However, empirical experience showed that their survival depends on specific conditions, such as public financial subsidies and involved types of goods (Danielis et al., 2010).

\subsection{Inadequate Offer of the Logistics Services}

The difference between the behavior and demands of consumers, households and business units on one side, and logistics services offered in response to the requests, on the other, is very noticeable in the cities. Behavioral changes in consumption have led to the changes in shopping trips. Shopping is currently performed in various places, including small local shops and grocery stores, local supermarkets, large supermarkets, mail, internet etc. This "variability" of the shopping places affects the complexity of the shopping journeys (different modes of transport are used, shopping is combined with other reasons for travelling), but also affects the creation of new demands for logistics services, such as home deliveries or deliveries to the special locations for collecting the goods (McLeod et al., 2006; Song et al., 2009).

Generators of the logistics flows, particularly retails, have increasing demands for the introduction of new logistics services, which can significantly change the organization of city logistics. The range of products is expanding, therefore the need for additional space for their display is growing, which confirms the fact that the storage areas within the retails are reducing (Smith et al., 2005), i.e. requirements for the storage of goods within the retails in the city is growing. Retails research in Lille and Tour (France) showed that $15 \%$ of these generators were interested and willing to pay for the storage space in the city. The same percentage of the retail owners was interested in the home delivery service, and about $8 \%$ for especially dedicated areas for receiving the goods. Besides that, one third of the retails have requirements for the reverse logistics services (collection of pallets and cardboard packaging) (Dablanc, 2007). In addition to the requirements for the collection of packaging and freight handling units, researches in Belgrade showed that about $1.5 \%$ of the delivered seasonal and perishable goods have the demand for the services of reverse logistics (Tadić, 2014).

The Logistics sector has launched a surprisingly small number of initiatives in response to the previously mentioned requirements. Many services are not offered by the logistics providers, at least not in a way that is specific to urban conditions. Even significant growth in e-commerce (EC, 2012) has not yet led to the specialization of city logistics. The most of the home deliveries are realized by the postal, courier or express services, while many logistics service 
providers are not interested in this market segment due to the many operational problems (Hesse, 2002). The prices of home deliveries are relatively high and they are considered to be the biggest obstacle for the future growth (Visser and Hassall, 2006). In addition, the failed delivery that may occur if the customer is not at home (at the given address) at the time of the delivery creates additional transport and environmental problems (Allen et al., 2008; Browne et al., 2001). According to the estimates, between 2 and $30 \%$ of home deliveries cannot be realized, which increases the activity of delivery vehicles and any related adverse effects (Edwards et al., 2009). Another problematic element of e-commerce is the realization of the flows of the returned products. Internet sales, in particular, are facing with the high rates of returns, because customers often do not know all the features of the product before buying. For example, online clothing retailers experienced the return rate of up to $45 \%$ of their orders (Tarn et al., 2003). The costs of handling the returned products, which include bridging the "last mile" for the second time, can easily destroy the economic viability of the on-line trade channels.

However, there are also positive examples of the initiatives in the sector of city logistics. In Germany, Deutsche Post / DHL group has implemented a network of automatic stations for collecting the goods, Packstation or 24 Tower (Niches, 2009). By placing Collection Delivery Point (CDP) stations, the problem of failed home deliveries can be solved and total distances of the shopping trips can be reduced by $16-53 \%$ (Song, 2008; Song et al., 2009). However, regardless to its practicality, e-commerce is still associated with dissatisfaction of users in terms of services, delivery in particular. The logistic service for which there is an increasing demand in some
European cities is a professional storage. Thus, the English company Shurgard, once renting the storage space for the households in London, later developed a storage service for retails and other generators in the city center (Dablanc, 2007).

\subsection{Centralization of the Supply Chain and Sub-Urbanization of the Logistics}

The size, population density and economic structure of the city, as well as the operational models and vehicle structure in the realization of flows, affect the extent and location of the logistics activities. Significant impact on logistics and urban areas has the strategic organization of the supply chains, i.e. spatial arrangements and locations of logistics centers and warehouse systems within the chain (Allen et al., 2012).

By the 1970, supply chains were relatively decentralized, with a larger number of warehouses, often at the point of production and in the immediate vicinity of the recipient, but also between these two points. This resulted in a large number of relatively small warehouses, i.e. logistics systems inside the urban areas, often in the city center and near the industrial zones. Factors that influenced the location of warehouse systems were the proximity of production facilities and markets, appropriate access to the road network and intermodal facilities, land cost and the availability of work force (McKinnon, 1989). Three trends affected the change of the location selection concept for the warehouse and logistics systems in the developed countries (Allen et al., 2012):

- De-industrialization has led to a decline in industrial production (as the main generator of goods and transportation activities) and the requirements for 
the production and warehouse systems in the urban areas of the developed countries (Hesse, 2008). Manufacturing activities are relocated to the countries of the Eastern Europe and Asia, where companies use lower labor costs. Relocation of production systems has led to the relocation of warehouse and logistics systems to these country, while the developed countries of Europe and America import the goods through the large and modern logistics centers near ports and freight villages along major transport corridors outside the urban areas (Bowen, 2008; Cidell, 2010; Woudsma et al., 2008).

- Spatial centralization of warehouse and logistics system in order to reduce the supply chain costs. The concept of a larger number of smaller warehouse systems is being abandoned and flows directed to the large national and regional logistics centers that serve the wider catchment area. Centralization is enabled through the development of transport infrastructure which has enabled companies to locate their logistics, i.e. warehouse systems, on the strategically important points characterized by the good hinterland availability. Freight villages, as logistical systems that serve national and international markets, have become a key element of the city's economy. Large, modern logistics and distribution centers tend to concentrate in the large urban areas (Cidell, 2010). Total inventories in the supply chain are reducing by the centralization and direction of the flows through the large logistics systems (McKinnon, 1989, 2009). On the other hand, centralization of the warehouse systems increases the costs of transport, but this growth is more than compensated by the savings from the centralization of inventories. Many supply chains are realized through the hub and spoke network of regional and national logistics centers in conjunction with local, urban centers, where goods are transshipped to the vehicles for local delivery.

- Increasing land prices and traffic congestion in the urban areas have forced companies to move their logistics systems at locations with relatively lower prices of land (Hesse, 2008). Since the logistic systems generates a large number of freight and delivery vehicles, causes the air pollution and emissions of greenhouse gases and noise and visually violate the city, logistics is becoming less present in the central and urban areas and tend to relocate to the suburban parts of the city. In addition, high costs of the urban land affected the limitation of storage space within commercial buildings and its commitment to support the core business activities that make profit (e.g. an increase of the sales space in the retail objects). This has led to the suburbanization of logistics (Allen et al., 2012) and relocation of the logistics systems to the suburban zones (Cidell, 2010; Dablanc and Rakotonarivo, 2010; Hesse, 2008; O’Connor, 2010; Woudsma et al., 2008).

Development of road freight transport (higher payload and speed) further supported the above-mentioned trends and moving of the logistics systems from the urban areas. The logistics sprawl or the sub-urbanization has serious consequences for the environment. Moving of the logistics systems away from the central urban areas increases the transport distances in the process of supplying, i.e. the kilometers traveled, and accordingly the greenhouse 
gas emissions, while the congestion that generate significant social costs grows. These facts are even more important if it is known that the majority of deliveries (over $2 / 3$ in the European cities), to and from the urban environment, are realized via the terminals and distribution centers located in the immediate vicinity. Research of the effects of the logistics sprawl on the $\mathrm{CO}_{2}$ emissions in Paris (Dablanc and Rakotonarivo, 2010) have contributed to raising awareness of the local authorities about these environmental challenges.

With the reduction of warehouse space, both in commercial activities, as well as in the production systems, demands for reliable, regular and flexible deliveries of relatively small quantities of goods is growing. This led to the implementation of JIT (Just In Time) strategy for the supply of urban facilities (Rodrigue, 2006; Taylor, 2001). Inventories are partially transferred to the transport system which causes the growth of traffic congestion and pollution, i.e. the growth of social costs. This is confirmed by empirical research in the UK: on a sample of 87 companies, the decrease of $39 \%$ in the storage capacity is identified, while one third of the companies had a larger volume of road transport (McKinnon, 1998). Part of the goods for supplying the city is not stored at all, but instead it is sorted inside the cross-docking terminals and immediately loaded onto the vehicles and delivered to the buyers (Bowen, 2008). Besides that, the trend of growing goods flows is continuing, which along with the growth of the urban population leads to the increased activities of road freight and light commercial vehicles.

Researches in the UK cities, for the period of 1998-2008, show an increase in surface area of trade and other commercial facilities and significant reduction of the production, i.e. industrial, surface areas. However, despite the centralization of logistics activities, surface areas of the storage systems have increased by $22 \%$. This indicates that the growth of goods flows, and thus the logistics activities, is greater than the reduction of warehousing space that occurred as a result of the spatial concentration of logistics systems. However, this growth is related to the suburban areas, while in the urban and central areas this resulted in the reduction of the surface areas under logistics systems (in London by $82 \%$ ). The growth in the number of warehouse systems was lower than the growth of their surface areas, which confirms the trend of centralization in the supply chain (Allen et al., 2012).

\subsection{Logistics Outsourcing}

A significant feature of the city logistics, since the eighties of the last century, is the growing trend of the logistics outsourcing. On the basis of cost and quality parameters, the companies are making a decision on whether to produce or purchase some products or services, i.e. whether they should pay someone to carry them out (MOB, make or buy). If a company realizes logistics activities cheaper than if someone was hired for their execution, then it should remain within the company. This concept is defined as the logistics insourcing. However, if it is more profitable for the company to hire someone to perform logistics activities, the outsourcing would be the right choice. This is in fact a process of buying services from the specialized companies which provide logistics services, i.e. the logistics providers.

Different operators and service providers appear in the processes of organization and realization of logistics activities in the city. 
Small enterprises (shopping, restaurants, craft, etc.) are mainly associated with the logistics insourcing. They perform themselves the processes of ordering, by purchasing the goods, packaging, transportation, by their own cars or vans, and warehousing and inventory, in the sales (catering, craft) premises or auxiliary warehouses. On the other hand, large companies with their own retail chains, large industrial complexes, manufacturers and wholesalers who have their own logistical subsystems (distribution centers, fleet, etc.), also belong to the category of the organizers and operators of activities for their own needs. The benefits of the inhouse realization of logistics activities are better control over trade flows and time and cost of the implementation of logistics activities, easier planning of transportation activities and their alignment with other activities, and marketing (vehicle serving as a mobile billboard), as an additional benefit. However, in the case of small quantities of goods, efficiency of logistics activities, particularly transport, and the possibility of flows consolidation are limited. Small companies usually realize direct deliveries, while the planning of the logistics activities in the larger companies is more complex. The logistics branch is often separating, legally and economically, from the parent company and can apply complex logistical concepts which emphasize the benefits of the flows consolidation (Zečević and Tadić, 2006).

Viewed over a longer period of time, the self-directed realization of cargo flows is in decline. This is the consequence of the higher demands for the service quality and offers of the additional services by the professional logistics service providers. Logistics service providers in addition to transport, also provide the services of warehousing, sorting, packing, etc. The senders or receivers of the goods can engage a logistics provider for the realization of individual services, most commonly transport (2PL - Second Party Logistics), or to enter into a long term contract for the execution of a wider range of logistics services (outsourcing level 3PL - Third Party Logistics). 2PL providers are mainly transport or shipping companies, often specialized in a particular type of goods or group of goods flow generators. Some companies combine their own and professional transport in a way that the regular part of the transport operations are carried out by their own, while for the off-peak requests (greater volumes or specific goods) they hire transportation companies. By leaving the logistics activities to the specialized logistic service providers (3PL providers), companies reduce costs and have more opportunities to develop core business. Logistics outsourcing, as the business system, is also desirable from the environmental perspective. For the purpose of efficiency, logistics providers realize consolidated deliveries to the objects in the city and have better utilization of vehicles cargo space, which reduces the number of delivery vehicles and vehiclekilometers traveled. Since the deliveries are consolidated, higher capacity vehicles can be used and the number of deliveries can be decreased (Whiteing and Edwards, 1997). Greater use of the logistics outsourcing affects the reduction of the total surface area of the warehouse systems and inventory levels, and on the other hand improves the service quality. The advantages of the outsourcing are increasingly used by the retail suppliers also. By entering the congested urban areas, operational costs increase and the profitability and 
competitiveness are becoming questionable. Logistics outsourcing gives suppliers the opportunity to deliver bulk, unpacked and unsorted goods to the providers' warehouses, available 24 hours and seven days a week, thus avoiding the congested city roads and reducing costs.

Logistics service providers in the urban areas are mostly small companies. In Europe, $85 \%$ of the companies providing goods distribution services have less than five employees. In Italy, the small individual carriers with mainly one vehicle (it. padroncini) realize $80 \%$ of deliveries in the urban areas. The situation is similar in the other parts of the world. In Mexico City, $80 \%$ of the private carriers are those who have less than five vehicles, and $70 \%$ of the total fleet of these companies is comprised of light commercial vehicles of a gross weight of up to 3.5 tones (Lozano, 2006).

In most cities, urban freight transport is very inefficient, i.e. the same amount of goods, with the same or better quality of service, can be delivered with a smaller number of vehicle-kilometers. This inefficiency is mostly associated with the companies that realize transport services by their own means (insourcing), and the studies have shown that smaller firms have a lower utilization factor of the vehicles cargo space (Kato and Sato, 2006). Companies in Africa, regardless of size, still have the logistics insourcing as a dominant business strategy. This means that they realize logistics activities, transport primarily, themselves, using their own systems, which explains the high cost of transport and logistics. In South Africa, inefficient use of commercial vehicles explains the high logistics costs (Joubert and Axhausen, 2011).

\subsection{Growth of the Urban Road Freight Transport}

Given that most of the goods flows begins or ends inside the city, it is clear why the road transport has the dominant role in the urban goods distribution. The reasons for the continuous growth of the urban freight transport are numerous, and some of them are: the growth of the urban population, the expansion of cities, new business strategies, relocation of the logistics systems to the outskirts of the city, the disappearance of the warehouse space from the facilities within the city, the growth of the share of commercial vehicles with the capacity less than $3.5 \mathrm{t}$, etc. In the European conurbations, over $80 \%$ of the road freight trips are realized at the distances of up to $80 \mathrm{~km}$, which is defined as an urban or urban-regional transport (Ruesch and Petz, 2008). Research conducted by Iveco in nine European countries, more than twenty years ago, showed that about $48 \%$ of vehicles operate within the city, and about $32 \%$ of the vehicles within the suburban areas (Eriksson, 1996). In Italy, the final destinations of $70 \%$ of the transported cargo are located within the region of origin. The transport distances for more than $50 \%$ of the goods are up to $50 \mathrm{~km}$, and for the $25 \%$ within the city itself (Ewers, 1994). Recent research in the UK showed that the urban freight transport almost doubled from 1972 until the beginning of this century, while the total quantity of goods increased slightly and the transport distances increased by $140 \%$. Analysis of the road freight transport with the vehicles of the gross weight exceeding 3.5 tones, in the period 1993-2003, showed the growth of $7 \%$ in the volume of goods transported and $15 \%$ in the average distance traveled (Browne et al., 2007). Given that 
the analysis did not include vans and pick-up trucks, the growth of urban freight transport is even higher.

The share of local freight transport depends on the size of the city, ranging from $15 \%$ of the total road freight transport in small towns, up to $40 \%$ in the large cities. In the period 1994-2004, in the UK there was a growth of road freight transport, expressed in vehicle-kilometers, by $9 \%$. The increase was greater in the streets of lesser importance (12\%) than in the major urban corridors (5\%). The most significant growth in the number of the travelled vehicle-kilometers had the light-duty vehicles with a payload of up to $3.5 \mathrm{t}$ (29\%) (Browne et al., 2007). In 2004, 150 million tons of cargo flows, realized by the road freight vehicles of a gross weight over $3.5 \mathrm{t}$, had the source and/ or destination in the Greater London area, whereas the 64 million tons of cargo flows (about 43\%) had the beginning and the end inside London. Commercial vehicles make up around $14 \%$ of the total vehicle-kilometers on the main streets of London. In addition, the total number of freight vehicles is also increasing, due to the stronger growth of the light commercial vehicles (DfT, 2005). In fact, the ratio of light and heavy road freight vehicles varies from country to country. In the UK, light commercial vehicles make up the largest part of the cargo vehicles, typically over $80 \%$ in the urban areas. The traffic of these vehicles in the urban areas has stable growth, while the traffic of heavy freight vehicles decreases (DfT, 2012).

Supplying the Paris, annually generates about 32 million tons of cargo (over 15 tons per capita), out of which 29.5 million tons is transported by the road (Dablanc, 2011). However, if the other flows (reverse flows, waste and transit flows) are added to this, the volume of road transport is significantly increased. According to the estimates, about 1.6 million deliveries/ collections per week is realized in Paris (Baybars and Dablanc, 2004), and it is expected that the road vehicle-kilometers will grow by $11 \%$ by the year of 2020 in the Ile de France region (Ripert, 2006). The researches show that commercial facilities, on the average, require 10 deliveries of the basic goods and 7.6 service runs per week, while before the holidays (Christmas) this activity of commercial vehicles increases by $25 \%$. Light-duty vehicles play a dominant role and realize $42 \%$ of all deliveries, with an average stay in front of the building of about $10 \mathrm{~min}$ (Cherrett et al., 2012). Given the growth of the total volume of traffic, the steady growth in the number of freight vehicles and the road freight transport in the urban areas is expected in the future (Crainic et al., 2009).

\subsection{The Loading Factor}

The loading factor is the percentage of the used capacity of the vehicles cargo space (payload in tones or volume in $\mathrm{m}^{3}$ ) and in case of an empty cargo space its value is 0 . It is already mentioned that the low degree of utilization of cargo space increases the number of delivery vehicles, i.e. the number of vehicle-kilometers in the urban areas. Even when there is a significant utilization of vehicles in one direction, reverse trips are mostly empty. The loading factor and the share of the empty vehicle runs represent the operational performances of the freight trips which are influenced by the various factors, such as: economic structure and land use, warehousing models and structure of the logistics chains, spatial and geographical features of the city, etc. These factors determine the overall activity of the freight 
vehicles needed to deliver a certain quantity of goods. The low loading factor of vehicles increases the companies' costs and adversely affects the environment and society. The costs of labor, fuel and consumables are almost the same, regardless of whether the vehicle is empty or not. Of course, some goods, due to their characteristics, makes it impossible to use the same vehicle for the transport of some other goods in the return run, but there is a significant range of goods for which this is feasible. Because of all the above, the loading factor of vehicles represents an issue with large reserves in the city logistics and is especially analyzed accordingly.

By applying the business strategies with the minimal inventory and scheduled deliveries, the loading factor is decreasing. In order to meet the increasingly stringent demands of the customers, logistics providers are often more focused toward the effective management of the time aspect then towards the efficient transport, which implies the increase of the running vehicles, and thus the vehicle-kilometers, and the decrease of the loading factors (Demkes et al., 1999). Factors that additionally influence the decline of the loading factors are the growth of the goods volumes (cargo spaces are generally full, but in the terms of area and volume) and the growth of the palletization, i.e. the changes on the market reflected in the trend of going from the bulk or unit loads towards the palettes. However, the development and greater use of the information technologies in the city logistics can compensate the previous influences.

Researches show that commercial vehicles in Europe have rather low factor of loading with the tendency of further decline. In road transport, it is below $50 \%$, and in the
Netherlands it fell from $43 \%$ to only $30 \%$ from 1997 to 2004 (Sathaye et al., 2006). In the UK, the loading factor of the national road transport decreased by $9 \%$ in the period 1982-2005. The decline of the loading factor is hiding some opposing trends. On the one hand, better management of the fleet reduced the number of the empty runs, but on the other hand, the loading factor of the vehicles in the loaded direction declined (DfT, 2008). It is estimated that empty runs make up about $25 \%$ of the freight vehicle-kilometers (McKinnon, 2003). The geographical imbalance, unsuitability of the vehicles and problems with routing and scheduling of the vehicles are some of the reasons for the still high share of the empty runs.

In the UK, the transport efficiency is highest in the incoming flows where the loading factor is $60-70 \%$, and lowest in the local deliveries, with a loading factor of about $40 \%$. In the outgoing flows, the loading factor is about $50 \%$ (Allen and Browne, 2010). The efficiency of the urban trips (tons-kilometers per vehicle-kilometer) is lower due to the lower average payload and lower loading factor. The trips going out of the city are less efficient than the trips going towards the city due to a lower loading factor and a higher share of empty runs as a result of an imbalance of incoming and outgoing flows to/from the urban area. In terms of transport intensity (traveled kilometers per ton of goods), trips inside the urban areas are generally less intense than those from and to the urban areas, and the reason is the shorter distance of the transport (Allen et al., 2012). However, the utilization of the cargo space surface is significantly larger than the utilization of the vehicle weight capacity. Research on the 22 road freight carriers' fleets revealed that the utilization of the cargo space surface is around $74 \%$ 
and of the weight capacity about 54\% (DfT, 2003c). This confirms the fact that the cargo space surface of the vehicle is often a limiting factor for the transport efficiency. In the European cities, the utilization factor of the cargo space volume of vehicles is increasing and in some cities reaches the value of $70 \%$ to $80 \%$ (Schoemaker et al., 2006), indicating a decreasing trend in specific mass of the load. The loading factor also depends on the type of load (higher for liquid and bulk cargo), sector of goods, but also from the transport distances (higher for longer distances) (EEA, 2005). Also, the loading factor is lower in the companies that realize the transport activities on their own (insourcing) (Kato and Sato, 2006). The presented data confirm that the loading factor represents a special reserve for improving the performance of city logistics. It is believed that the inclusion of the external transport costs would contribute to a significant increase in total costs, and that the loading factor, i.e. the better vehicle utilization, would become a goal that must be achieved.

\subsection{Environmental Impacts and the Quality of Life}

The dominant share and the growing trend of road transport in the realization of the goods flows negatively affect sustainability. These impacts are related to the environment (emissions, consumption of non-renewable energy, waste and loss of ecosystems), society (damage to human health, accidents, noise and reduced quality of life) and the economy (reliability and accessibility decrease, price increase, etc.) (Quak, 2008). Due to the traffic congestion, the travel time is extending, placement of the products to the market is delaying and delivery costs are increasing. This can be easily converted into a monetary value because time is money. Traffic congestion on certain sections of the road network are the reason for the use of the alternative routes, which may be longer and less safe, thereby increasing transportation costs and risk. These additional costs are passed through the supply chain and transferred onto the end user. Over time, this translates into a general loss for the society. Residents are the ultimate generators of the commodity and transport flows, but they do not support the disorders that result from the attempts of meeting the market demands. With the increase in the number of freight vehicles, the road safety is reducing. Characteristics of the roads, types of vehicles, driver training and traffic management are typically not considered in the process of routes planning for the freight vehicles. Due to these failures, the number of accidents and damage to infrastructure, i.e. roads, is increasing. The growing trend in traffic volumes reflects to the environment through the high fuel consumption, which natural resources are regenerating more slowly than they are consumed. In addition, the gas emissions and noise levels are increasing.

Freight transport is therefore in a permanent rift between efficient logistics and sustainable development. On the one hand, timed, and less frequent deliveries hinder the achievement of the economies of scale in transport, while on the other hand, there is an increasing pressure for reducing the negative impacts on the environment. This is the most significant challenge in the urban areas. Although the freight transport represents only $20-30 \%$ of the road traffic in the city, it generates $20-60 \%$ of all emissions originating from the traffic (one-third of emissions of $\mathrm{NO}_{x}$ and a quarter of $\mathrm{CO}_{2}$ emissions) (Dablanc, 2007). According to the above mentioned and described 
problems, the goal of the city logistics is the improvement of the efficiency of logistics activities, primarily of transport, through the reduction and control of the number, size and characteristics of the freight vehicles, and the number of empty vehicle-kilometers in the city.

Effectiveness and efficiency of the logistics activities in the urban environment, not only affect the local and regional productivity, but also the quality of life in the city (Albalate and Bel, 2009). Externalities originating from the transport (without congestion) in the year of 2000 were estimated at $7.3 \%$ of the GDP in the EU15, Norway and Switzerland (INFRAS / IWW, 2004). Freight traffic is responsible for the third of the external costs (including congestion), and the road freight transport has a dominant role. Unsustainable impacts of the transport are many. Some impacts are local in character and tangible only at the sites of the realization of the transport activities (e.g. the noise), while some have a regional character over a longer period of time (e.g. emissions of the greenhouse gases). The scale of the local impact is determined by the population density of the sites on which the transport activities are taking place. Therefore the unsustainable impacts of the freight transportation are the largest in the urban areas (CE Delft, 2008). In addition, the structure and the higher average age of the vehicles, as well as the operating regimes with a large number of trips over short distances and a large number of stopping, make the urban freight transport less sustainable than the long haul transport of goods.

Key impacts are related to the human health and the environment (noise, air pollution, traffic safety, etc.). In addition, there are also broader impacts that affect welfare, including congestion and associated stress and social exclusion. In 2006, the cost of congestion in the EU amounted to $1 \%$ of the GDP (EC, 2006), and the most significant component represent the congestion in the urban areas (EC, 2007b). According to the projections, the growth of up to $50 \%$ by the year of 2050 is expected (EC, 2011).

\section{Conclusion}

Logistics, despite the fact that it encourages the urban economy, is still quite neglected in the terms of research and planning. Logistics service providers are focused on their own business, and individually and without coordination implement activities according to the customers' requirements, with the aim of delivering the right goods at the right place at the right time. In most cases, the realization of flows is successful, but it is not always the most appropriate in the terms of ecology and society.

With the spatial expansion of the cities, development of transport infrastructure and growth of the urban land prices, the stopping points of the macro-distribution flows are shifting towards the peripheral areas. The growth of the road transport, expansion of the network of warehouses and logistics centers, as well as the increased demands in terms of quality and diversity of logistics services, have resulted in a significant increase in the number of commercial vehicles and a worrying loss of the vitality of some cities. In many countries, national and local authorities have tried to implement some concepts of city logistics, but with varying success. From the aspect of planning, the city authorities are mainly dealing with the current situation and shortterm solutions to problems. Regulation of 
logistics activities is mainly confined to the use of the city ordinances that define the time of delivery, dimensions or payload of the delivery vehicles. Rare are the cities in which the logistics is seen as the service that need help in order to be organized in a more efficient manner. However, from the end of the last century, with the growth of the awareness and concern about the impacts of the logistics activities on the economic, environmental and social sustainability of the cities, the importance of the city logistics is also growing.

City logistics should be the subject of the national strategic plans, as well as spatial, transport and traffic plans of the local authorities. The objectives of these plans should be the reduction of the obstacles for the realization of the cargo flows, optimization of the existing logistics capacities, promotion of the environmental protection and the development of the diversity, efficiency and competitiveness of the logistics and transport infrastructure. In this sense, an integrated approach in all phases of the city logistics planning is required, from the phase of observing the problems and goals of the participants and environment, through the definition of the alternative solutions, modeling and assessment of the effects, to the implementation and exploitation phase. Since the integrated planning involves all aspects of sustainability, city logistics solution is becoming widely accepted and doesn't only affects the efficiency of logistics and the socio-economic system of the city, but the sustainability of the entire region.

For the purpose of admissibility, successful implementation and sustainability of the solutions, the participation of all stakeholders in their definition should be encouraged using the appropriate methods, and the effects, i.e. the consequences, for the entire system of the city logistics should be considered. However, changes in the problem solving approaches and the integrated planning require a certain level of understanding of the nature of logistics activities, which is usually not the case.

\section{References}

Albalate, D.; Bel, G. 2009. What Local Policy Makers Should Know about Urban Road Charging: Lessons from Worldwide Experience, Public Administration Review, 69(5): 962-974.

Allen, J.; Browne, M. 2010. Considering the relationship between freight and urban form. Transport Studies Department, University of Westminster, London.

Allen, J.; Anderson, S.; Browne, M.; Jones, P. 2000. A framework for considering policies to encourage sustainable urban freight traffic and goods/service flows. Transport Studies Group, University of Westminster, London.

Allen, J.; Browne, M.; Cherrett, T. 2012. Investigating relationships between road freight transport, facility location, logistics management and urban form, Journal of Transport Geography. DOI: http://dx.doi.org/10.1016/j. jtrangeo.2012.06.010, 24: 45-57.

Allen, J.; Thorne, G.; Browne, M. 2008. Good Practice Guide on Urban Freight Transport. BESTUFS consortium.

Anderson, S.; Allen, J.; Browne, M. 2005. Urban logistics: how can it meet policy makers' sustainability objectives?, Journal of Transport Geography. DOI: http:// dx.doi.org/10.1016/j.jtrangeo.2004.11.002, 13(1): 71-81.

Ballantyne, E.; Lindholm, M.; Whiteing, A. 2013. A comparative study of urban freight transport planning: addressing stakeholder needs, Journal of Transport Geography. DOI: http://dx.doi.org/10.1016/j. jtrangeo.2013.08.013, 32: 93-101. 
Baybars, M.; Dablanc, L. 2004. Meeting the challenges of urban freight in European cities: The cases of London and Paris. In Proceedings of the 10th World Conference on Transport Research, Istanbul, Turkey.

Benjelloun, A.; Crainic, T.G.; Bigras, Y. 2010. Towards a taxonomy of City Logistics projects, Procedia - Social and Behavioral Sciences. DOI: http://dx.doi.org/10.1016/j. sbspro.2010.04.032, 2(3): 6217-6228.

Bowen, J. 2008. Moving places: the geography of warehousing in the US, Journal of Transport Geography. DOI: http://dx.doi.org/10.1016/j.jtrangeo.2008.03.001, 16(6): 379-387.

Browne, M.; Allen, J.; Anderson, S.; Jackson, M. 2001. Overview of Home Deliveries in the UK. University of Westminster/Freight Transport Association.

Browne, M.; Piotrowska, M.; Woodburn, A.; Allen, J. 2007. Literature Review WM9: Part I - Urban Freight Transport, University of Westminster.

CE Delft (Committed to the Environment). 2008. Handbook on Estimation of External Cost in the Transport Sector. Produced within the Study Internalisation Measures and Policies for All external Cost of Transport (IMPACT). CE Delft, Delft.

Cherrett, T.; Allen, J.; McLeod, F.; Maynard, S.; Hickford, A.; Browne, M. 2012. Understanding urban freight activity - key issues for freight planning, Journal of Transport Geography. DOI: http://dx.doi.org/10.1016/j. jtrangeo.2012.05.008, 24: 22-32.

Cidell, J. 2010. Concentration and decentralisation: The new geography of freight distribution in U.S. metropolitan areas, Journal of Transport Geography. DOI: http://dx.doi.org/10.1016/j.jtrangeo.2009.06.017, 18(3): 363-371.

Crainic, T.G.; Ricciardi, N.; Storchi, G. 2009. Models for evaluating and planning city logistics systems, Transportation Science, 43(4): 432-454.
CSCMP (Council of Supply Chain Management Professionals). 2012. $23^{\text {rd }}$ Annual State of Logistics Report. Council of Supply Chain Management Professionals.

Dablanc, L. 2007. Goods transport in large European cities: Difficult to organize, difficult to modernize, Transportation Research Part A: Policy and Practice. DOI: http://dx.doi.org/10.1016/j.tra.2006.05.005, 41(3): 280-285.

Dablanc, L. 2009. Freight Transport for Development Toolkit: Freight Transport. World Bank.

Dablanc, L. 2011. TURBLOG D3.1: Urban Logistics practices - Paris Case study. NEA Transport research and training.

Dablanc, L.; Rakotonarivo, D. 2010. The impacts of logistic sprawl: How does the location of parcel transport terminals affect the energy efficiency of goods' movements in Paris and what can we do about it?, Procedia-Social and Behavioral Sciences. DOI: http://dx.doi. org/10.1016/j.sbspro.2010.04.021, 2(3): 6087-6096.

Danielis, R.; Rotaris, L.; Marcucci, E. 2010. Urban freight policies and distribution channels, European Transport, 46: 114-146.

Demkes, R.; Ter Brugge, R.; Verduin, T. 1999. TRILOGEurope Summary Report. TNO Inro, Delft, Netherlands.

DfT. 2003a. A guide on how to set up and run Freight Quality Partnerships, Good Practice Guide. Department for Transport, London, Great Britain.

DfT. 2003b. Freight Quality Partnerships: Case Studies, Good Practice Case Study. Department for Transport, London, Great Britain.

DfT. 2003c. Benchmarking guide 77: Key Performance Indicators for Non-Food Retail Distribution. Department for Transport, London, Great Britain.

DfT. 2005. Transport of Goods by road in Great Britain: 2004. Department for Transport, London, Great Britain. 
DfT. 2008. Delivering a Sustainable Transport System: The Logistics Perspective. Department for Transport, London, Great Britain.

DfT. 2012. Road traffic (vehicle $k m s$ ) by vehicle type and road class in Great Britain. Department for Transport, London, Great Britain.

EC. 2004. A cleaner, greener Europe. LIFE and the European Union waste policy. Office for Official Publications of the European Communities, Luxemburg.

EC. 2006. Keep Europe Moving-Sustainable Mobility for Our Continent - Mid-term Review of the European Commission's 2001 White Paper on Transport, COM(2006) 314 final. Office for Official Publications of the European Communities, Luxemburg.

EC. 2007a. Sustainable Urban Transport Plan. Preparatory Document in relation to the follow-up of the Thematic Strategy on the Urban Environment, Technical Report $-2007 / 018$.

EC. 2007b. Green Paper: Towards a new culture for urban mobility. Office for Official Publications of the European Communities, Luxemburg.

EC. 2011. White Paper: Roadmap to a single European transport area - Towards a competitive and resource efficient transport system, $\operatorname{COM(2011)~} 144$ final. Office for Official Publications of the European Communities, Luxemburg.

EC. 2012. Consumer conditions scoreboard, 7th edition. Directorate-General for Health and Consumers, European Commission, Brussels.

Edwards, J.B.; McKinnon, A.C.; Cullinane, S.L. 2009. Carbon auditing the'last mile': modelling the impact of conventional and on-line food shopping. Herriott-Watt University, Green Logistics Project.

EEA. 2005. Load factors in freight transport. Indicator Fact Sheet, TERM 2005 30, European Environment Agency.
EEA. 2010a. The European environment - state and outlook 2010: consumption and the environment. European Environment Agency.

EEA. 2010b. CSI-17. Core set of indicators 017, Generation and recycling of packaging waste. European Environment Agency.

ELA (European Logistics Association). 2004. Differentiation for performance excellence in logistics 2004. Deutscher Verkehrs-Verlag.

Eriksson, J.R. 1996. Urban freight transport forecasting - an empirical approach. Urban Transport and the Environment II, Computational Mechanics Publications.

Esser, M.; Petry, K. 1993. City logistik center: Chance für eine ökonomische und ökologische Versorgung von Ballungsräumen. In Distribution.

Ewers, H.J. 1994. Meinungen zur City-Logistik - Der Wissenschaftler: Nicht mit der Brechstange. Der Handel 9:28.

Geurs, K.; van Wee, B. 2004. Land-use/transport interaction models as tools for sustainability impact assessment of transport investments: Review and research perspectives, European Journal of Transport and Infrastructure Research, 4: 333-355.

Gonzalez-Feliu, J.; Ambrosini, C.; Pluvinet, P.; Toilier, F.; Routhier,J.L. 2012. A simulation framework for evaluating the impacts of urban goods transport in terms of road occupancy, Journal of Computational Science. DOI: http:// dx.doi.org/10.1016/j.jocs.2012.04.003, 3(4): 206-215.

Goodman, R.W. 2005. Whateveryou call it, just don't think of last-mile logistics, last. Global Logistics and Supply Chain Strategies. Keller International Publishing Corporation.

Hesse, M.; Rodrigue, J.P. 2004. The transport geography of logistics and freight distribution, Journal of Transport Geography. DOI: http://dx.doi.org/10.1016/j. jtrangeo.2003.12.004, 12(3): 171-184. 
Hesse, M. 2002. Shipping news: the implications of electronic commerce for logistics and freight transport, Resources, Conservation and Recycling. DOI: http://dx.doi. org/10.1016/S0921-3449(02)00083-6,36(3): 211-240.

Hesse, M. 2008. The City as a Terminal: The Urban Context of Logistics and Freight Transport. Ashgate, Aldershot.

Holguin-Veras, J.; Cruz, C.; Ban, X. 2013. On the comparative performance of urban delivery vehicle classes, Transportmetrica A: Transport Science. DOI: http://dx.doi.org/10.1080/18128602.2010.523029 , $9(1): 50-73$.

IAURIF (Institut d'aménagement et d'urbanisme d'Ilede-France). 1999. Les marchandises: Ile de France, Tokyo, New York. Cahiers de l'IAURIF, No 128.

INFRAS/IWW. 2004. External Costs of Transport-Update Study. INFRAS, IWW Universität Karlsruhe, Zürich, Karlsruhe.

Joubert, J.W.; Axhausen, K.W. 2011. Inferring commercial vehicle activities in Gauteng, South Africa, Journal of Transport Geography. DOI: http://dx.doi. org/10.1016/j.jtrangeo.2009.11.005, 19(1): 115-124.

Kato, H.; Sato, J. 2006. Urban Freight Transportation analysis in Developing Countries: Case Study in Medan, Indonesia. Non published.

Loffler, P. 1999. City Logistics: A Contribution to Sustainable Development? - A contribution to the discussion on solutions to freight transport problems in urban areas, World Transport Policy and Practice, 5(2): 4-10.

Lozano, A. 2006. Estudio integral metropolitano de transporte de carga y medio ambiente para el Valle de México (EIMTC$M A V M)$. Final Report. Universidad Autonoma de México, Comision Ambiental Metropolitana.

McKinnon, A. 1989. Physical Distribution Systems. Routledge, London.
McKinnon, A. 1998. Logistical restructuring, freight traffic growth and the environment. In: Banister, D. (ed.), Transport policy and the environment, Routledge, New York, 97-109.

McKinnon, A. 2003. Logistics and the Environment. In: Hensher, D.A. \& Button, K.J. (eds.) Handbook of Transport and the Environment, Pergamon, Amsterdam, 665-685.

McKinnon, A. 2005. The economic and environmental benefits of increasing maximum truck weight: the British experience, Transport Research Part D: Transport and Environment. DOI: http://dx.doi.org/10.1016/j. trd.2004.09.006, 10(1): 77-95.

McKinnon, A. 2009. The present and future land requirements of logistical activities, Land Use Policy. DOI: http://dx.doi.org/10.1016/j.landusepol.2009.08.014, 26(1): 293-301.

McLeod, F.; Cherrett, T.; Song, L. 2006. Transport impacts of local collection/delivery points, International Journal of Logistics: Research and Applications. DOI: http:// dx.doi.org/10.1080/13675560600859565, 9(3): 307-317.

Niches, 2009. Alternative solutions for home delivery. Niches, European Commission, Brussels

O'Connor, K. 2010. Global city regions and the location of logistics activity, Journal of Transport Geography. DOI: http://dx.doi.org/10.1016/j.jtrangeo.2009.06.015, 18(3): 354-362.

OECD (Organisation for Economic Co-operation and Development). 2003. Delivering the Goods: 21st Century Challenges to Urban Goods Transport, OECD Publishing.

Ogden, K.W. 1992. Urban Goods Movement: A Guide to Policy and Planning. Ashgate, Aldershot.

PORTAL. 2003. Inner Urban Freight Transport and city logistics, Written Material. Available from Internet: $<$ www.eu-portal.net>. 
Quak, H.; de Koster, M.B. 2009. How to Deal with Urban Policy Restrictions and the Environment, Transportation Science, 43(2): 211-227.

Quak, H. 2008. Sustainability of urban freight transport Retail Distribution and Local Regulations in Cities. Erasmus Research Institute of Management (ERIM), Erasmus University, Roterdam, PhD.

Ripert, C. 2006. Paris Freight Policy Programme and Effects. BESTUFS Annual Conference, Malta.

Rodrigue, J.P. 2006. Challenging the derived transport-demand thesis: geographical issues in freight distribution, Environment and Planning A: Environment and Planning, 38(8): 1449-1462.

Rodrigue, J.P.; Comtois, C.; Slack, B. 2009. The Geography of Transport Systems. Routledge, New York.

Ruesch, M.; Petz, C. 2008. E-Commerce and urban freight distribution (home shopping). Best Practice Update (2008). Updated Handbook from Year 2001. BESTUFS Consortium.

Sathaye, N.; Li, Y.; Horvath, A.; Madanat, S. 2006. The Environmental Impacts of Logistics Systems and Options forMitigation. Working paper, UC Berkeley Center for Future Urban Transport.

Schoemaker, J.; Allen, J.; Huschebeck, M.; Monigl, J. 2006. Quantification of Urban Freight Transport Effects I, BESTUFS II. BESTUFS Consortium.

Smith, A.; Watkiss, P.; Tweddle, G.; McKinnon, A. et al. 2005. The Validity of Food Miles as an Indicator of Sustainable Development. DEFRA, London.

Song, L. 2008. Transport and Environmental Impacts of Current Home Delivery Services and the Benefits of Alternative Measures. Faculty of Engineering, Science and Mathematics, School of Civil Engineering and the Environment, University of Southampton, PhD.
Song, L.; Cherrett, T.; McLeod, F.; Guan, W. 2009. Addressing the last mile problem-the transport impacts of collection/delivery points. Presented at the 88th Annual Meeting of the Transportation Research Board, Washington, DC.

Stathopoulos, A.; Valeri, E.; Marcucci, E. 2012. Stakeholder reactions to urban freight policy innovation, Journal of Transport Geography. DOI: http://dx.doi. org/10.1016/j.jtrangeo.2011.11.017, 22: 34-45.

Tadić, S.; Zečević, S.; Petrović-Vujačić, J. 2013a. Global trends and logistics development (in Serbian: Globalni trendovi i razvoj logistike), Ekonomski vidici, 18(4): 519532 .

Tadić, S.; Zečević, S.; Krstić, M. 2013b. Locating city logistics terminal using fuzzy AHP analysis - case of Belgrade (in Serbian: Lociranje city logističkog terminala primenom fazi AHP analize - primer Beograda), Tehnika, 68(4): 707-716.

Tadić, S. 2014. Integrated city logistics solutions performance modelling (in Serbian: Modeliranje performansi integrisanih city logističkih sistema), Faculty of Transport and Traffic Engineering, University of Belgrade, PhD.

Tadić, S.; Zečević, S.; Krstić, M. 2014a. Ranking of Logistics System Scenarios for Central Business District, Promet - Traffice Transportation, 26(2): 159-167.

Tadić, S.; Zečević, S.; Krstić, M. 2014b. City logistics initiatives aimed at improving sustainability within existing context of urban area (in Serbian: Inicijative city logistike u cilju poboljšanja održivosti unutar postojećeg konteksta urbane sredine), Tehnika, 61(3): 487-495.

Tadić, S.; Zečević, S.; Krstić, M. 2014c. A novel hybrid MCDM model based on fuzzy DEMATEL, fuzzy ANP and fuzzy VIKOR for city logistics concept selection, Expert Systems with Applications. DOI: http://dx.doi. org/10.1016/j.eswa.2014.07.021, 41(18): 8112-8128. 
Tadić, S.; Zečević, S.; Krstić, M. 2014d. City logistics initiatives aimed at improving sustainability by changing the context of urban area (in Serbian: Inicijative city logistike u cilju poboljšanja održivosti promenom konteksta urbane sredine), Tehnika, 61(5): 834-843.

Tadić, S.; Zečević, S. 2015. Integrated planning aimed at sustainability city logistics solutions (in Serbian: Integrisano planiranje u cilju održivosti rešenja city logistike), Tehnika, in press.

Tarn, J.M.; Razi, M.A.; Wen, H.J.; Perez Jr, A.A. 2003. E-fulfillment: The strategy and operational requirements, Logistics Information Management, 16(5): $350-362$

Taylor, S. 2001. Just-in-time. In: Brewer, A., Button, D. \& Hensher, D. (eds.), Handbook in Transport 2: Handbook of Transport, Supply Chain and Logistics. Pergamon, Kidlington, 213-224.

TNO (Toegepast Natuurwetenschappelijk Onderzoek). 2003. De invloed van venstertijden en voertuigbeperkingen op de distributiekosten in de Nederlandse detailhandel, TNO Inro.

UN (United Nations). 2012. World Population Prospects: The 2011 Revision. United Nations, New York.
Visser, J.; Hassall, K. 2006. The future of city logistics: estimating the demand for home delivery in urban areas. In: Taniguchi, E. \& Thompson, R. G. (eds.), Recent advances in city logistics, Elsevier, Oxford, 147-161.

Whiteing, A.E.; Edwards, S.J. 1997. Goods Deliveries in City Centres: Have we got the policy balance right? In Freight, proceedings of seminar B held at PTRC European Transport Forum, Brunel University, Vol.P412, 67-77.

Woudsma, C. 2001. Understanding the movement of goods, not people: Issues, evidence and potential, Urban Studies. DOI: http://dx.doi. org/10.1080/00420980120094605, 38(13): 2439-2455.

Woudsma, C.; Jensen, J.; Karoglou, P.; Maoh, H. 2008. Logistics land use and the city: A spatialtemporal modeling approach, Transportation Research Part E: Logistics. DOI: http://dx.doi.org/10.1016/j. tre.2007.07.006, 44(2): 277-297.

Zečević, S.; Tadić, S. 2006. Citylogistics (in Serbian: City logistika). Faculty of Transport and Traffic Engineering, University of Belgrade, Belgrade. 